\title{
Yield Response of the Puerto Rico and Columnaris Coffee Cultivars in Two Latosols of Puerto Rico, as Affected by Different Levels of Nitrogen, Phosphorus, Potassium, and Lime ${ }^{1}$
}

\author{
Saulo J. Rodriguez, R. Bosque-Lugo, R. Pérez-Pérez, and \\ A. Rodriguez-Cabrera ${ }^{2}$
}

\section{INTRODUCTION}

Coffee is the second most important agricultural crop in Puerto Rico. Available statistics for the years 1949-61 showed an average production per year of 253,761 hundredweights of market coffee with an estimated value of 13.6 million dollars. For the year 1959-60, coffee production represented 7.2 percent of our Island's agricultural gross-production value (5). ${ }^{3}$

The estimated area devoted to coffee in Puerto Rico is around 160,000 cuerdas. ${ }^{4}$ Most of this land is located in the mountainous west-central part of the Island. The average production is less than 200 pounds of market coffee per cuerda. The low production has been attributed to factors such as inadequate manuring in quality and quantity, too much shade, lack of selection of planting material, no systematic pruning, mixed plantations with citrus and bananas, improper soil conservation practices, and insufficient population per unit area.

The problem of fertilizing coffee is very confused. In 1960-61, coffee farmers used a total of 11,300 tons of mixed fertilizer, i.e., or approximately 142 pounds per cuerda. For the year 1961-62, the fertilizer applied increased to 14,450 tons i.e., an average of 180 pounds per cuerda. Fifteen different fertilizer mixtures were available for coffee manuring (2). The mixtures varied from a low of 8 units of nitrogen to a maximum of 20 . The phosphorus had a range from 3 units of $\mathrm{P}_{2} \mathrm{O}_{5}$ to a maximum of 12 . The potassium fluctuated between 5 and 20 units of $\mathrm{K}_{2} \mathrm{O}$.

The purpose of the work reported here was to determine how different

1 This work was carried on under Federal project H-20. Several have worked on this project since the beginning, in 1945 . The authors appreciate the help of all these persons, and the cooperation of many farmers as well.

${ }^{2}$ Associate Horticulturist, Gurabo Substation; Assistant Agronomist in Charge, Adjuntas Substation; Research Assistant in Agronomy, Adjuntas Substation; Agronomist in Charge, Corozal Substation, Agricultural Experiment Station, University of Puerto Rico, Río Piedras, P.R.

3 Italic numbers in parentheses refer to Literature Cited pp. 261-2.

4 A cuerda is equal to 0.97 of an acre. 
levels of nitrogen, phosphorus, and potassium affected the coffee yields. Observations were also made on the effects of liming on coffee yields.

\section{REVIEW OF LITERATURE}

Very little research has been reported from Puerto Rico on the response of coffee to different levels of major nutrients.

McClelland (7), working in an alluvial-fan soil, reported a favorable response of coffee to applications of potash, if accompanied by nitrogen. In the same work an adverse effect of high levels of nitrogen was observed, if not accompanied by enough potassium. No response to phosphorus was observed in the fertilizer test. On the other hand, Gómez, et al. (6), working in a lateritic soil, found a significant response in yield to phosphorus applications in coffee under shade. No response to either nitrogen or potash was obtained. Recently, Abruña, Vicente, and Silva (1) found that coffee grown without shade responded significantly to potassium, especially when accompanied by nitrogen. Yields of over 1,800 pounds of market coffee per acre were obtained in the experimental plots.

\section{PROCEDURE}

Two sites were selected for the study. The soils were of the Catalina and Alonso series. Both are heavily leached lateritic soils common in the coffeegrowing area of Puerto Rico.

The Catalina soil was located at an altitude of 1,100 feet above sea level in the western part of the Island while the Alonso soil was located at 1,600 feet above sea level in the center of the coffee-growing area of the Island.

Uniform seedlings of the Puerto Rico and Columnaris coffee cultivars were planted at spaces of $8 \times 8$ and $12 \times 12$ feet, respectively, at each of the two sites. Mixed shade of leguminous trees and bananas was used in the experimental plots. Annual pruning was used to keep the shade at about 50 percent.

Lime was applied to the treatments requiring it, and the $\mathrm{pH}$ was increased to 6.5 at the beginning of the experiment. No additional limestone was applied from there on.

A paired-plot experimental design with 17 treatments and 16 replications was used in both sets of experiments ( 8 ). Cultural practices in common use at the coffee farms were employed throughout the development of the studies.

During the picking season ripened berries were harvested at 15-day intervals until the last picking. In the last harvest both ripened and green, hard berries were gathered at the same time.

Statistical analysis of the data was performed for both the annual crop and the combined crops. This paper covers 10 years of combined data. Statistical analyses were carried on at the Statistical Section of the Agri- 
TABLE 1.-Response of 2 coffee cultivars to different levels of major nutrients in a Calalina clay at Maricao

\begin{tabular}{|c|c|c|c|c|}
\hline \multicolumn{3}{|c|}{ Description of treatments 1} & \multicolumn{2}{|c|}{ Yields } \\
\hline $\mathbf{N}$ & $\mathrm{P}_{2} \mathrm{O}_{6}$ & $\mathrm{~K}_{2} \mathrm{O}$ & $\begin{array}{l}\text { Columnaris } \\
12 \times 12 \mathrm{ft} \text {. }\end{array}$ & $\begin{array}{l}\text { Puerto Rico } \\
8 \times 8 \text { it. }\end{array}$ \\
\hline$L b . / A$ & $L b . / A$ & $L b . / A$ & Crot./A & $C w t . / A$ \\
\hline 0 & 250 & 250 & 4.10 & 3.56 \\
\hline 50 & 250 & 250 & 4.78 & 3.86 \\
\hline 100 & 250 & 250 & 4.02 & 5.26 \\
\hline 150 & 250 & 250 & 4.54 & 5.18 \\
\hline 200 & 250 & 250 & 4.74 & 5.53 \\
\hline 250 & 0 & 250 & 5.03 & 4.76 \\
\hline 250 & 50 & 250 & 4.60 & 4.97 \\
\hline 250 & 100 & 250 & 4.23 & 5.05 \\
\hline 250 & 150 & 250 & 4.71 & 4.54 \\
\hline 250 & 200 & 250 & 4.61 & 5.20 \\
\hline 250 & 250 & 0 & 4.14 & 5.14 \\
\hline 250 & 250 & 50 & 5.02 & 4.19 \\
\hline 250 & 250 & 100 & 4.56 & 4.66 \\
\hline 250 & 250 & 150 & 4.49 & 3.43 \\
\hline 250 & 250 & 200 & 4.29 & 4.59 \\
\hline 250 & 250 & 250 & 4.46 & 5.18 \\
\hline
\end{tabular}

${ }^{1}$ All treatments were limed to $\mathrm{pH} 6.5$ at the beginning of the experiment.

TABLE 2.-Response of 2 coffee cullivars to different levels of major nutrients in an Alsono clay at Castañer

\begin{tabular}{|c|c|c|c|c|}
\hline \multicolumn{3}{|c|}{ Description of treatments! } & \multicolumn{2}{|c|}{ Yields } \\
\hline $\mathrm{N}$ & $\mathrm{P}_{\mathbf{2}} \mathrm{Ob}_{6}$ & $\mathrm{~K}=\mathrm{O}$ & $\begin{array}{l}\text { Columnaris } \\
12 \times 12 \text { ft. }\end{array}$ & $\begin{array}{l}\text { Puerto Rico } \\
8 \times 8 \mathrm{ft} \text {. }\end{array}$ \\
\hline$L b . / A$ & $L b . / A$ & $L b . / A$ & Crot./A & Cwt./A \\
\hline 0 & 250 & 250 & 3.25 & 4.36 \\
\hline 50 & 250 & 250 & 3.20 & 4.24 \\
\hline 100 & 250 & 250 & 3.70 & 3.83 \\
\hline 150 & 250 & 250 & 3.75 & 5.35 \\
\hline 200 & 250 & 250 & 4.01 & 5.88 \\
\hline 250 & 0 & 250 & 3.82 & 3.87 \\
\hline 250 & 50 & 250 & 3.58 & 5.98 \\
\hline 250 & 100 & 250 & 3.36 & 4.48 \\
\hline 250 & 150 & 250 & 4.27 & 4.64 \\
\hline 250 & 200 & 250 & 3.43 & 6.04 \\
\hline 250 & 250 & 0 & 3.27 & 4.01 \\
\hline 250 & 250 & 50 & 3.96 & 5.74 \\
\hline 250 & 250 & 100 & 4.36 & 4.43 \\
\hline 250 & 250 & 150 & 4.09 & 5.74 \\
\hline 250 & 250 & 200 & 3.67 & 5.33 \\
\hline 250 & 250 & 250 & 5.77 & 5.15 \\
\hline
\end{tabular}

${ }^{1}$ All treatments were limed to $\mathrm{pH} 6.5$ at the beginning of the experiment. 
cultural Experiment Station, following Capó's method (3). After obtaining the corrected mean yields for the different increments in the nutrients applied, a parabolic curve was fitted to the results.
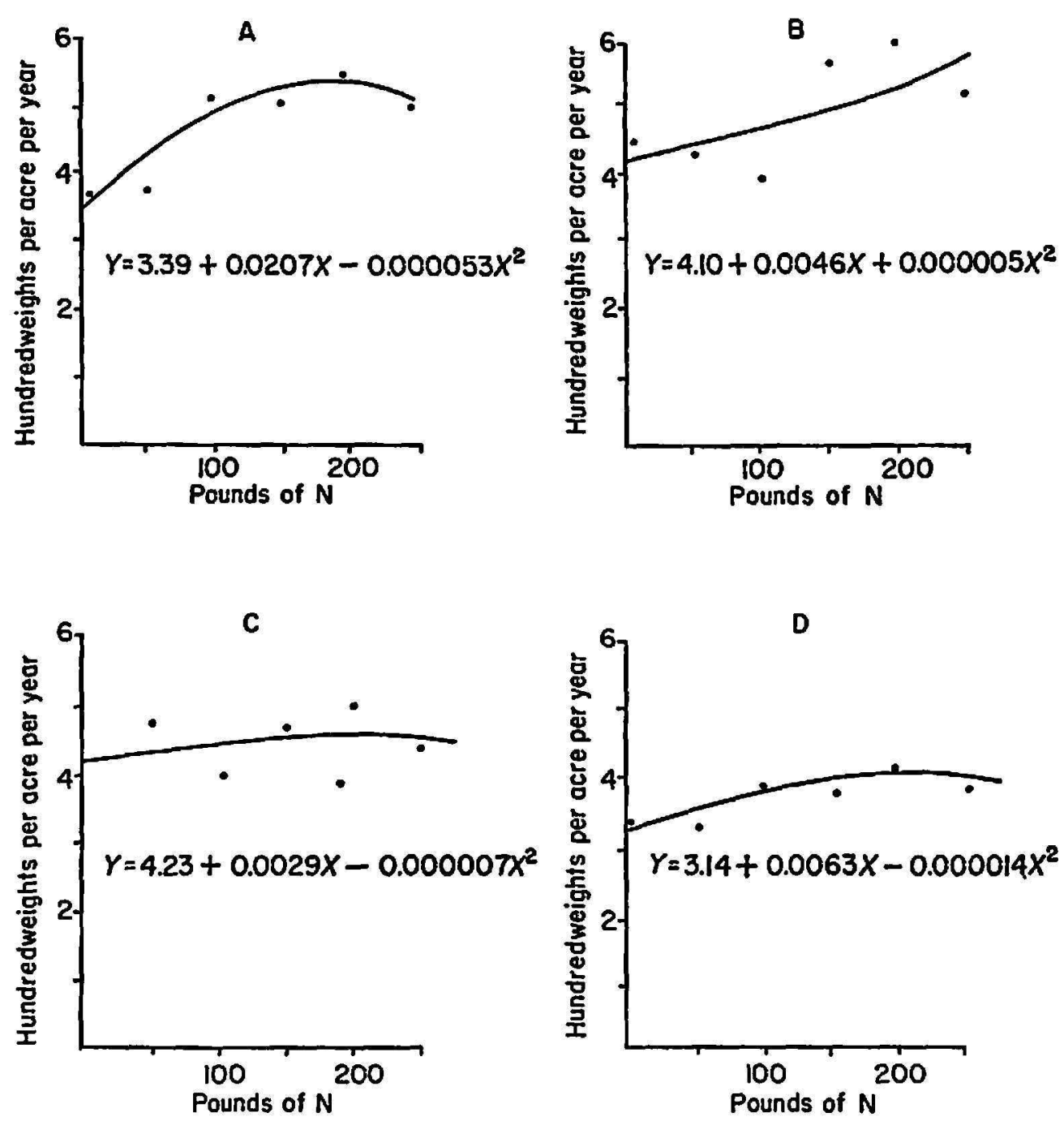

Frg. 1.-The effects of levels of nitrogen on coffee yields: A, Puerto Rico at Maricao; B, Puerto Rico at Castañer; C, Columnaris at Maricao; D, Columnaris at Castañer.

\section{RESULTS AND DISCUSSION}

The effects of the different levels of the major nutrients used in the coffee experiments hereby reported are presented in tables 1 and 2 . Since there was no clear-cut effect of the increases in the levels of nitrogen, phosphorus, or potassium, a study of the data was made on the assumption of a diminishing return for each increase in the level of each nutrient. The results are presented in figures 1 to 3 .

It is generally accepted that nitrogen is the first limiting element for 
growth and yields in most of the cultivated crops. That should be more clearly seen under tropical temperature, light, and humidity. In our case, the results did not confirm this (fig. 1). Only the nitrogen yield curve for the Puerto Rico coffee at Maricao in the Catalina clay proved to be significant. Maximum yields were obtained at 200 pounds of $N$ per acre per
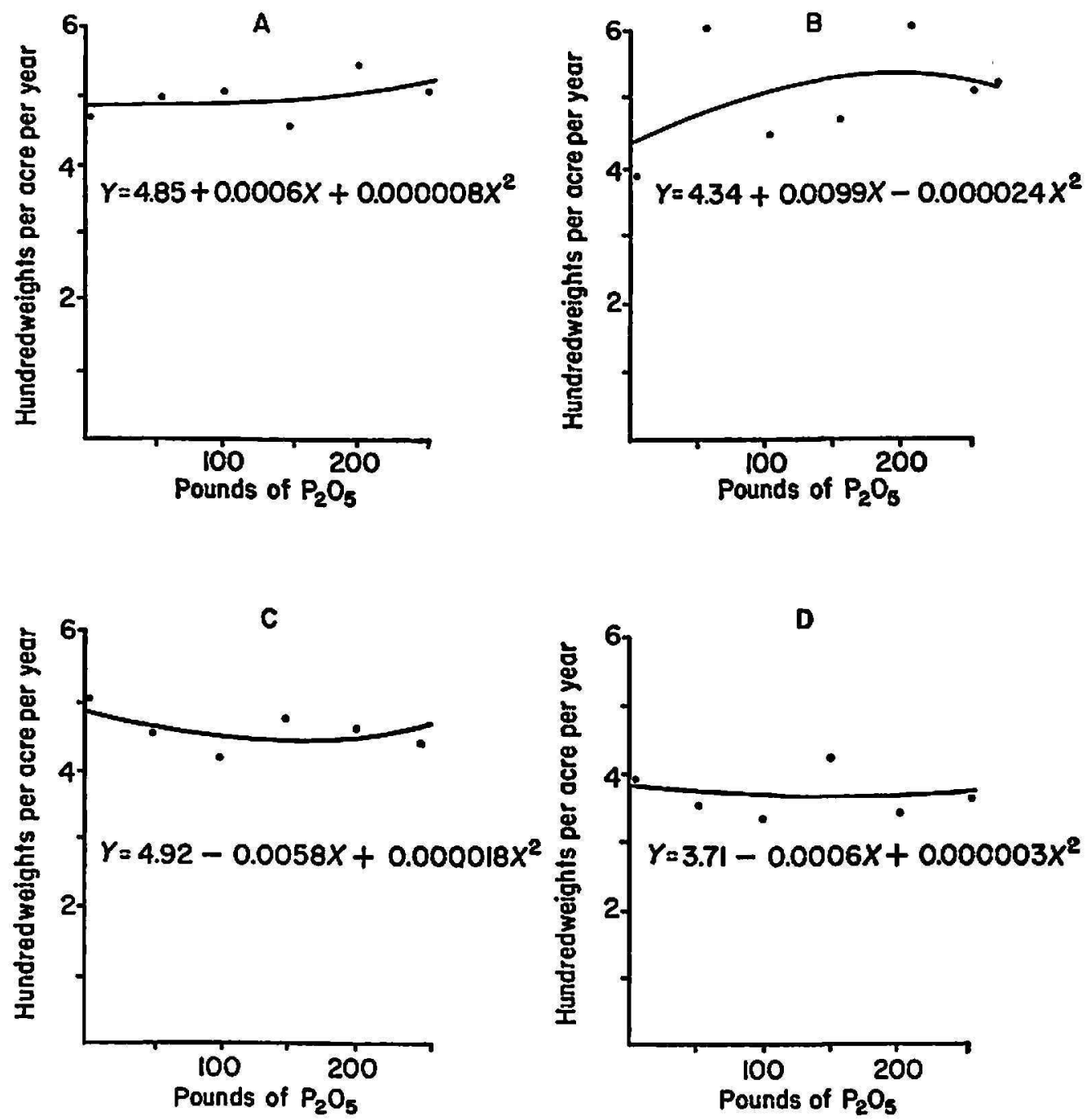

Fig. 2.-The effects of levels of phosphorus on coffee yields: A, Puerto Rico at Maricao; B, Puerto Rico at Castañer; C, Columnaris at Maricao; D, Columnaris at Castañer.

year, when accompanied by 300 pounds of $\mathrm{P}_{2} \mathrm{O}_{5}$ and $\mathrm{K}_{2} \mathrm{O}$ per acre per year, respectively. In the other experiments though there was an actual increase in yield with the increases in the levels of nitrogen, butnone of these increases was significant.

None of the curves for phosphorus or potassium for either of the two coffee cultivars at the two locations proved to be significant.

It is difficult to give a definite explanation for the lack of response of 
coffee to the three main nutrients. It is generally accepted in fruit nutrition that nitrogen and potash are the main limiting elements in growth yield (4). There is no definite reason for a lack of response of coffee to the three main elements. Apparently, factors such as variability in planting material, in the
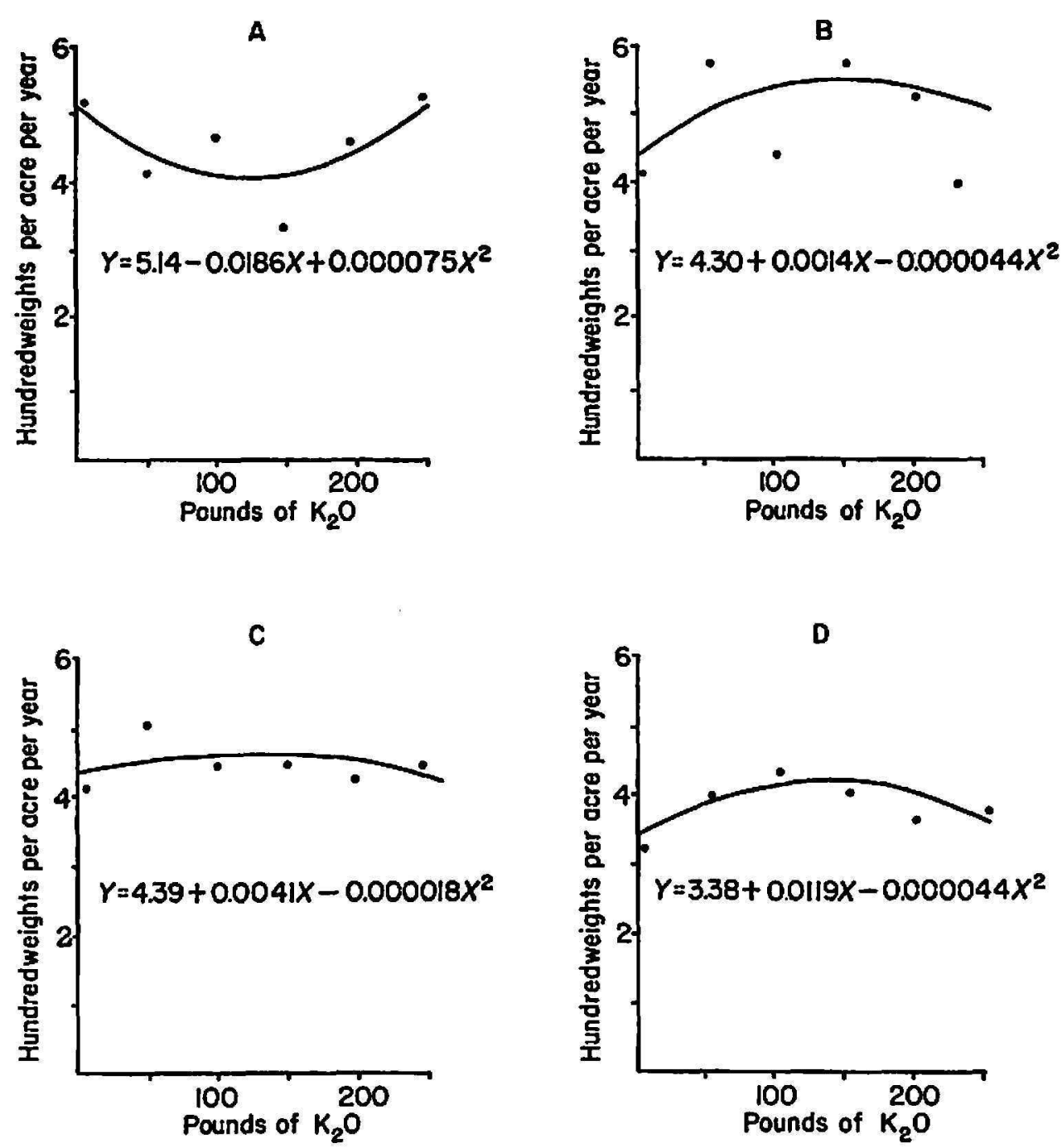

Fig. 3.-The effects of levels of potassium on coffee yields: A, Puerto Rico at Maricao; B, Puerto Rico at Castañer; C, Columnaris at Maricao; D, Columnaris at Castañer.

experimental sites, and in shade may mask the results, requiring a higher difference in treatments for significant differences in yields.

Liming when accompanied by nitrogen, phosphorus, and potash (table 3) did not significantly affect the yields. It is considered by most research workers that coffee is an acid-loving plant, though there is the possibility of a response to liming in soils in which manganese and aluminum may be present in toxic amounts. Under these conditions iron can become the limiting factor in reducing the yields, thus requiring lime applications or chelated iron applications $(8,9)$. 


\section{SUMMARY}

A set of four experiments with increasing levels of the three main plant nutrients and liming were established in two lateritic soils at two locations in the coffee-growing area of Puerto Rico. Two coffee cultivars were used in the experiments. The results obtained can be summarized as follows:

1. Nitrogen levels significantly affected coffee yields of the Puerto Rico cultivar in a Catalina clay at Maricao grown under shade.

2. Phosphorus and potassium did not significantly affect the yields of these coffee cultivars at the two locations.

3. Liming did not significantly affect the yields.

TABLE 3.-Response of 2 coffee cultivars to lime applications

\begin{tabular}{|c|c|c|c|c|}
\hline \multirow{3}{*}{ Treatments' } & \multicolumn{4}{|c|}{ Adjusted mean yields in cwt./A } \\
\hline & \multicolumn{2}{|c|}{ Alonso clay at Castañer } & \multicolumn{2}{|c|}{ Catalina clay at Maricao } \\
\hline & $\begin{array}{l}\text { Columnaris } \\
12 \times 12 \mathrm{ft} \text {. }\end{array}$ & $\begin{array}{l}\text { Puerto Rico } \\
8 \times 8 \mathrm{ft} \text {. }\end{array}$ & $\begin{array}{l}\text { Columnaris } \\
12 \times 12 \mathrm{ft} \text {. }\end{array}$ & $\begin{array}{l}\text { Puerto Rico } \\
8 \times 8 \mathrm{ft} \text {. }\end{array}$ \\
\hline $\begin{array}{l}\text { Lime } \\
\text { No lime }\end{array}$ & $\begin{array}{l}3.77 \\
3.11\end{array}$ & $\begin{array}{l}5.15 \\
4.65\end{array}$ & $\begin{array}{l}4.46 \\
4.50\end{array}$ & $\begin{array}{l}5.18 \\
4.32\end{array}$ \\
\hline $\begin{array}{l}\text { Difference }{ }^{2} \\
\text { L.S.D. } 5 \text { percent }\end{array}$ & $\begin{array}{l}0.66 \text { n.s. } \\
.88\end{array}$ & $\begin{array}{l}0.50 \text { n.s. } \\
2.19\end{array}$ & $\begin{array}{l}0.04 \text { n.s. } \\
.98\end{array}$ & $\begin{array}{l}0.86 \text { n.s. } \\
1.15\end{array}$ \\
\hline
\end{tabular}

${ }^{1} \mathrm{Major}$ nutrients were applied at the rate of $250 \mathrm{lb}$. of $\mathrm{N}, \mathrm{P}_{2} \mathrm{O}_{5}, \mathrm{~K}_{2} \mathrm{O}$, respectively, per acre per year.

${ }^{2}$ n.s. $=$ not significant.

\section{RESUMEN}

Una serie de cuatro experimentos con niveles incrementados de los tres nutrimentos de plantas principales se estableció en dos suelos lateríticos en dos localidades de la zona cafetalera de Puerto Rico. Se usaron dos tipos de café, Puerto Rico y Columnaris, en estos experimentos. Pueden resumirse los resultados como sigue:

1. Los niveles de nitrógeno afectaron significativamente los rendimientos de café del tipo Puerto Rico en un suelo Catalina arcilloso, en Maricao, bajo sombra.

2. El fósforo y el potasio no afectaron significativamente los rendimientos de ambos tipos de café en las dos localidades.

3. La aplicación de cal no afectó significativamente los rendimientos.

\section{LITERATURE CITED}

1. Abruña, F., Vicente-Chandler, J., and Silva, S., The effect of different fertility levels on yields of intensively managed coffee in Puerto Rico, J. Ayr. Univ. P.R. 43 (3) 141-6, 1959. 
2. Boletín Mensual de Estadísticas Agrícolas, Departamento de Agricultura E.L.A. de P.R., Negociado de Estadísticas Agrícolas, 2 (10), Octubre, 1962.

3. Capó, B. G., A new method of performing field trials, J. Agr. Univ. P.R., 28 (1) 22-34, 1944.

4. Childers, N. F., ed., Mineral Nutrition of Fruit Crops, Somerset Press, Somerville, N.J., 907 pp., 1954.

5. Facts and Figures in Puerto Rico's Agriculture, Planning Board, E.L.A. of Puerto Rico, Spec. Pub. No. 5, April, 1962.

6. Gómez, L. A., Lería-Esmoris, J., and Capó, B. G., Fertilizer requirements for coffee grown in a Catalina clay in Puerto Rico, J. Agr. Univ. P.R. 30 (3) 127-37, 1946.

7. McClelland, T. B., Experiment with Fertilizer for Coffee in Puerto Rico, B. 31, Porto Rico Agr. Expt. Sta., 34 pp., 1926.

8. Medcalf, J. C., and Lott, W. L., Metal Chelates in Coffee, B. 11, I.B.E.C. Research Institute, New York, N.Y. 19 pp., 1956.

9. Sachs, B., and Sylvain, P. G., editors, Advances in Cofiee Production, Technology, Coffee and Tea Industries, New York, N.Y., 95 pp., 1959. 